\title{
Progestogen-Androgen Combination: Results of Indonesian Clinical Trials
}

\author{
Kiagus Muhammad Arsyad
}

\begin{abstract}
Abstrak
Makalah ini menyarikan hasil dua penelitian klinis WHO yang dilaksanakan di Indonesia dalam upaya mendapatkan kombinasi progestogen-androgen yang cocok sebagai kontrasepsi pria dan mengidentifikasi masalah untuk penelitian dan pengembangan di masa datang. Penelitian pertama menggunakan kombinasi DMPA dan TE yang diberikan secara injeksi intramuskular dengan interval satu bulan dan 2 macam dosis: $100 \mathrm{mg}$ DMPA dan $100 \mathrm{mg}$ TE; $200 \mathrm{mg}$ DMPA dan $250 \mathrm{mg}$ TE. Penelitian ke dua adalah penelitian banyak sentra di Indonesia dimana tiap relawan diberi kombinasi DMPA dan TE atau kombinasi DMPA dan 19-NT. Pada kedua kelompok, $250 \mathrm{mg}$ DMPA diinjeksikan IM pada minggu ke 0, 6, 12, dan 18, dan $200 \mathrm{mg}$ TE atau $200 \mathrm{mg}$ 19-NT diberikan tiap minggu untuk 7 minggu pertama dan selanjutnya tiap tiga minggu sampai minggu ke 24. Hasil yang menggembirakan yang didapat dari dua penelitian ini memberikan harapan untuk mengembangkan suatu kontrasepsi yang aman, efektif dan cocok uniuk pria Indonesia. Walaupun masih diperlukan penelitian dan pengembangan untuk mendapatkan hormon yang dapat diberikan lebih praktis dan degan dosis yang lebih
rendah.
\end{abstract}

\begin{abstract}
This article summarizes the results of two recent WHO supported clinical studies in Indonesia to assess the potential of progestogen-androgen combinations as a male method of fertility regulation and identifies some areas for future research and development. The first study was carried out with a combination of DMPA plus TE given by intramuscular injection at monthly intervals and at two dose levels: $100 \mathrm{mg}$ DMPA plus $100 \mathrm{mg} \mathrm{TE;} 200 \mathrm{mg}$ DMPA plus $250 \mathrm{mg}$ TE. The second study is a multicentre study which is carried out in Indonesia, in which male volunteers received either a combination of DMPA and TE or a combination of DMPA plus 19-NT. In both cases, $250 \mathrm{mg}$ DMPA was injected IM at week 0, 6, 12, and 18, and $200 \mathrm{mg}$ TE or $200 \mathrm{mg} 19-N T$ was given weekly for the first seven weekls and then at 3-weekly intervals until week 24. The encouraging results obtained in these two studies offer a good prospect for developing a safe and effective hormonal contraceptive methods suitable for use by Indonesian men. However, the frequency of injection and the high levels of hormones that needed to be injected would make the development of such a method difficult with the currently available compounds.
\end{abstract}

Keywords: Male hormonal contraceptives, progestogen-testosterone regimen, Indonesian men.

Compared with the extensive research that has been carried out on methods for women, the amount of attention that has been given to the development of contraceptive methods for men is inadequate. The condom and coitus interruptus are the only reversible methods of contraception currently available to men. Both are usually started on the initiative of the couple and often without any medical advice. There is clearly a need for an improvement in the number and type of contraceptive methods for men, in order to expand family planning options for individuals and couples. The International Conference on Population and Development (ICPD) in Cairo, Egypt, called on governments to "increase the participation and sharing

Division of Andrology, Department of Medical Biology Faculty of Medicine, Sriwijaya University, Palembang, Indonesia of responsibility of men in the actual practice of family planning." ${ }^{1}$ Research in this field should be multifaceted with the goal of developing a range of fertility regulation methods to meet the needs of men of different social, cultural, and ethnic backgrounds.

Male fertility has been described as being regulated by three main factors: ${ }^{2}$ (i) the hormonal determinant which regulates steroidogenesis and spermatogenesis; (ii) the male accessory glands and organs which are under strict hormonal control and which are responsible for the production of the seminal plasma; (iii) the psychogenic determinant which controls masculine behavior and male libido.

The hormonal suppression of spermatogenesis depends on inhibiting the secretion of endogenous gonadotrophins (usually both LH and FSH, or FSH alone) and the correction of androgen deficiency by appropriate androgen supplementation. Clinical trials 
of various hormonal contraceptive agents for men have been supported by national and international agencies. ${ }^{3,4}$ The agents that have been tested in such trials include: androgens alone or in combination with progestogens; danazol; GnRH agonists and antagonists, and the data obtained in these studies have been reviewed recently. $5,6,7$

The main advantages of hormonal approaches to male contraception that have been investigated to date, is that they involve the use of agents that have been used in clinical therapy for many years, such as testostrone enanthate (TE) and GnRH agonists, and for which the toxicology is well defined. In addition, the suppression of spermatogenesis by these means has been shown to be fully reversible in preclinical studies in non-human primates as well as in clinical trials in men. However, the currently hormonal approaches have a number of problems associated with their use, including: (i) the failure to achieve azoospermia in all men, especially men of Caucasian origin; (ii) the lack of means to provide stable physiological androgen substitution; (iii) the absence of long-acting or orally active agents; (iv) the need for a prolonged period (several months) of treatment before the contraceptive effects are induced and; (v) the relatively high cost of these reagents (e.g. GnRH antagonist).

An ideal male contraceptive method would be a preparation that would not inhibit masculine behaviour and male libido, but would completely inhibit the production of spermatozoa - or inhibit the fertilizing capacity of spermatozoa - for the desired period of contraception.

It is with this goal in mind, that the WHO Task Force on Methods for the Regulation of Male Fertility has been conducting researches to develop safe, effective, reversible and acceptable methods of fertility regulation for men since 1972. The need for research on male methods of contraception and for a greater involvement of men in reproductive health have been promoted by many national and international agencies, women's health groups and governments, including that of Indonesia.

This article summarizes the results of two WHO supported clinical trials that have been carried out recently in Indonesia to assess the potential of combined progestogen-androgen injections as an approach to the regulation of male fertility. Both studies were pharmacokinetic/pharmacodynamic studies to assess the effect of the treatment on the subjects'spermatogenesis and biochemistry; they did not involve assessment of the contraceptive effect of the treatment by determin- ing the pregnacy rates in the partners of the treated men. In addition, these studies identified some areas for future research and development.

\section{PROGESTOGEN ANDROGEN COMBINATION AND THEIR EFFECT ON MALE FERTILITY}

\section{Depot Medroxy Progesterone Acetate and Tes-} tosterone Enanthate

In the first study done by Pangkahila, ${ }^{8}$ a combination regimen of depot medroxy progesterone acetate (DMPA) plus Testosterone Enanthate (TE) was given by intramuscular injection at monthly intervals and at two dose levels. One group of men $(n=10)$ received 100 $\mathrm{mg}$ DMPA plus $100 \mathrm{mg}$ TE and a second group of men $(\mathrm{n}=10)$ received $200 \mathrm{mg}$ DMPA plus $250 \mathrm{mg}$ TE (Table 1).

Table 1. The résumé of hormonal method clinical trials in Indonesia

\begin{tabular}{|c|c|c|c|}
\hline \multirow[t]{2}{*}{ No. } & \multirow[t]{2}{*}{ Variables } & \multicolumn{2}{|c|}{ Results of studies } \\
\hline & & Pangkahila & Multicentres \\
\hline 1. & Hormones & $\mathrm{DMPA}+\mathrm{TE}$ & $\begin{array}{l}\text { DMPA + TE } \\
\text { DMPA + 19-NT }\end{array}$ \\
\hline 2. & Dosages (mg) & $\begin{array}{l}100+100 \\
200+250\end{array}$ & $\begin{array}{l}250+200 \\
250+200\end{array}$ \\
\hline 3. & Intervention & IM-monthly & $\begin{array}{l}\text { TE or } 19-\mathrm{NT} \text { : } \\
\text { IM-weekly- } \\
7 \text { weeks/IM + } \\
3 \text { weekly-to week } 24 \\
\text { DMPA: IM-6 weekly- } \\
\text { to week } 18\end{array}$ \\
\hline & $\begin{array}{l}\text { (Suppression } \\
\text { Time) }\end{array}$ & $\begin{array}{l}4 \text { months } \\
\text { (18 weeks) }\end{array}$ & 24 weeks \\
\hline 4. & $\begin{array}{l}\text { Number of } \\
\text { Injection }\end{array}$ & 4 & 14 \\
\hline 5. & $\begin{array}{l}\text { Time to } \\
\text { Achieving } \\
\text { Azoospermia }\end{array}$ & $\begin{array}{l}2.5 \text { months } \\
(20 \text { weeks })\end{array}$ & 20 weeks \\
\hline 6. & $\%$ Azoospermia & $\begin{array}{l}100 \% \\
100 \%\end{array}$ & $\begin{array}{l}95.6 \% \\
97.8 \%\end{array}$ \\
\hline 7. & Recovery Time & 2.0 months & 6.5 months \\
\hline
\end{tabular}

A total of twenty men aged from 27 to 38 years were recruited. All but one were married and had fathered at least one child. At entry into study, their anthropometric data, mean (SEM), were as follows: height $165.8(1.0) \mathrm{cm}$, weight $64.2(2.1) \mathrm{kg}$, body surface area $1.71(0.003) \mathrm{m} 2$, body mass index $23.3(0.7) \mathrm{kg} / \mathrm{m} 2$ and mean testicular volume $27.8(0.9) \mathrm{ml}$. 
The side effects of treatment were considered minimal and none of the subjects discontinued the study. All men reported an increase in libido and sexual frequency during the treatment periods. Five volunteers noted a fall in their libido 1-2 months after cessation of injections, but libido was restored and normal sexual function returned during the subsequent three months.

Most of the subjects (19/20) reported weight gain (3.7 $\pm 0.5 \mathrm{~kg}$, range $0-9 \mathrm{~kg}$ ) at the end of the treatment period, which remained above the pre-treatment level at the end of the study $(67.4 \pm 2.0 \mathrm{~kg})$. Facial acne was noted in one man and another complained of nonspecific weakness and sleepiness which did not interfere with his daily work.

The proportion of men with azoospermia in both groups is illustrated in Figure 1. The rate and degree of reduction in sperm concentrations in the two groups were similar and the combined mean sperm-concentration is illustrated in Figure 2. Azoospermia was achieved at a median time of 2.5 months from the start of injections and sperm reappeared in the ejaculate at a median time of 2 months after cessation of injections.

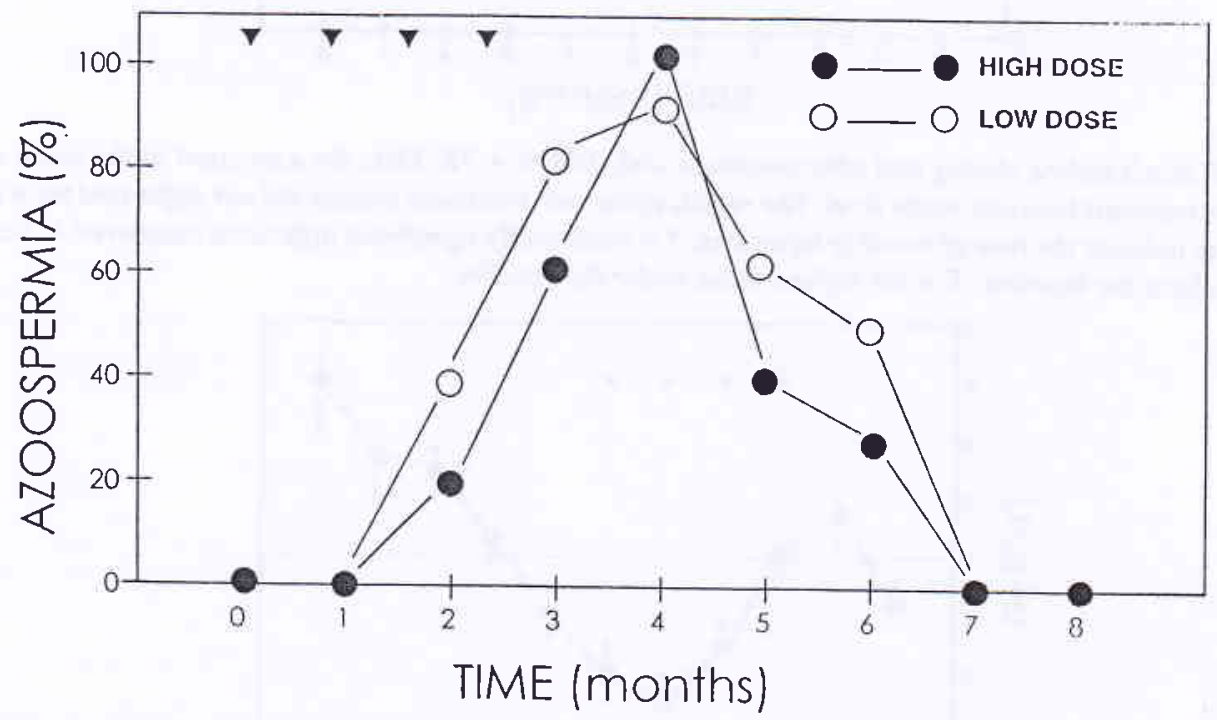

Figure 1. Proportion of azoospermic men during and after treatment with high dose (200 $\mathrm{mg} D M P A+250 \mathrm{mg}$ TE, filled circles) and low-dose (100 mg DMPA + $100 \mathrm{mg} T E$, open cicles). Filled inverse triangles indicate the time of monthly injection.

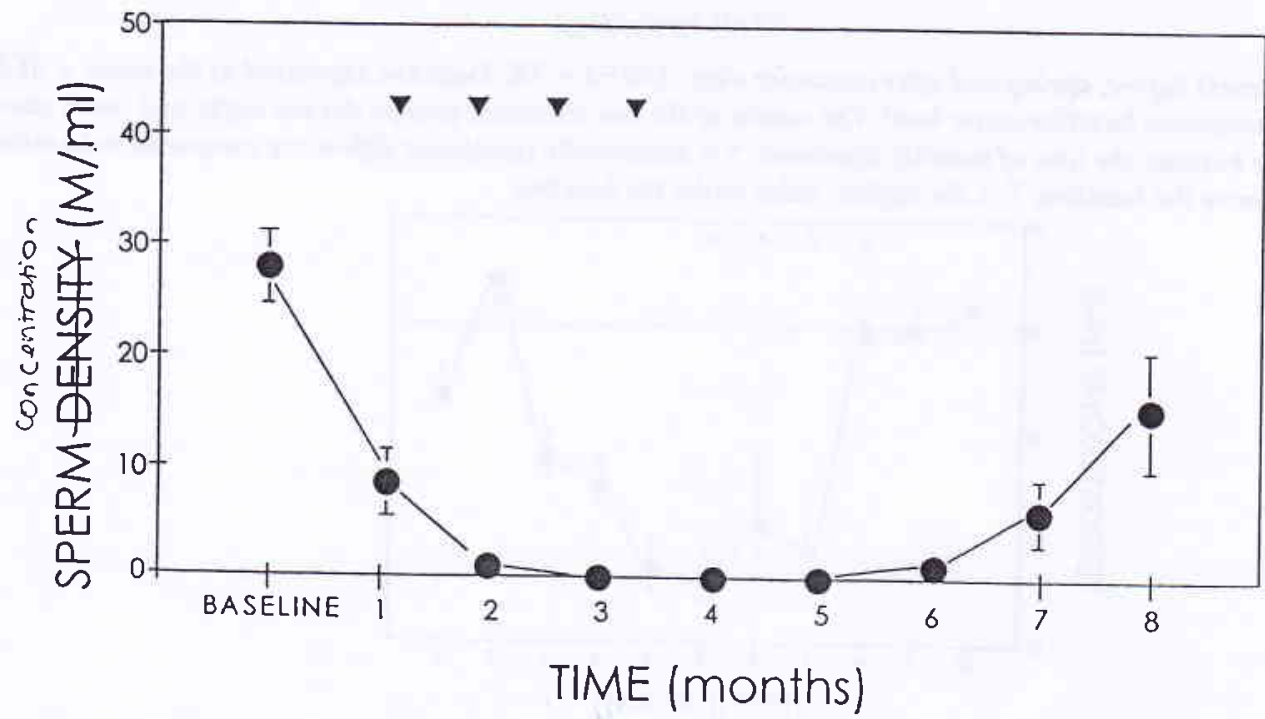

Figure 2. Mean sperm concentration before, during and after treatment with DMPA +TE. The mean sperm concentration of the two treatment groups did not differ and are combined (mean=solid circles, $\pm S E M$ ). Filled inverse triangles indicate the time of
monthly injections, $M / \mathrm{ml}=$ million $/ \mathrm{ml}$. 
Plasma levels of LH, FSH and testosterone were suppressed during the administration of steroids, and recovered after cessation of injections (Figure 3-5). Levels of testosterone recovered slowly and returned

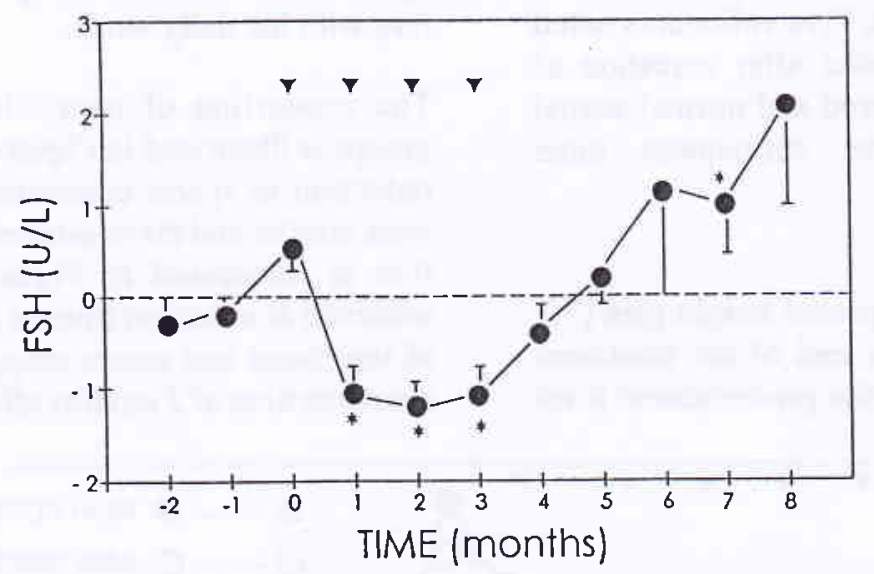

Figure 3. Plasma-FSH levels before, during and after treatment with DMPA +TE. Data are expressed as the mean $+S E M$ of the change from the pre-treatment baseline-mean level. The results of the two treatment groups did not differ and were combined. Filled inverse triangles indicate the time of monthly injections, * = statistically significant difference compared to baseline, $\perp=$ the lowest value above the baseline, $T=$ the highest value under the baseline.

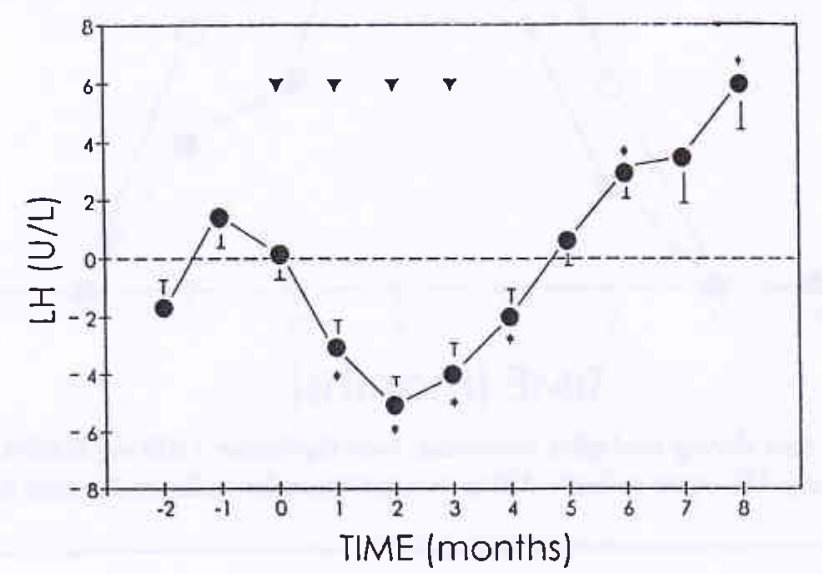

Figure 4. Plasma-LH levels before, during and after treatment with DMPA +TE. Data are expressed as the mean $+S E M$ of the change from the pre-treatment baseline-mean level. The results of the two treatment groups did not differ and were combined. Filled inverse triangles indicate the time of monthly injections, * = statistically significant difference compared to baseline, $\perp=$ the lowest value above the baseline, $T=$ the highest value under the baseline.

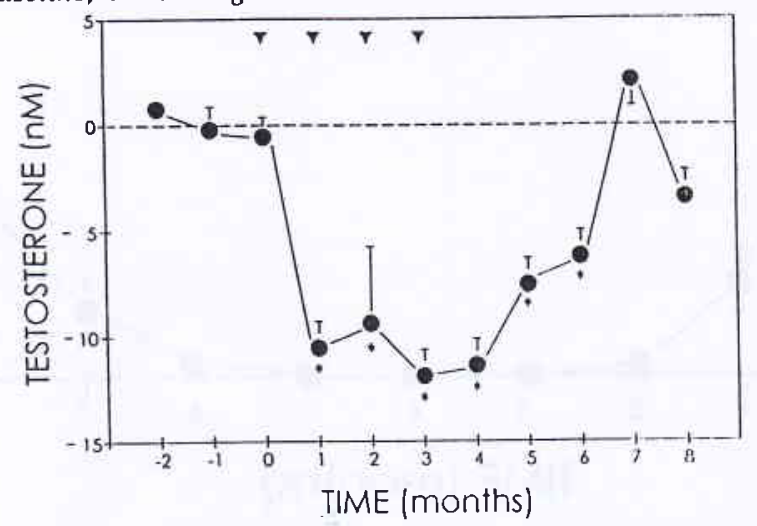

Figure 5. Plasma-testosterone levels before, during and after treatment with DMPA + TE. Data are expressed as the mean + SEM of the change from the pre-treatment baseline-mean level. The results of the two treatment groups did not differ and were combined. Filled inverse triangles indicate the time of monthly injections, ${ }^{*}=$ statistically significant difference compared to baseline, $\perp=$ the lowest value above the baseline, $T=$ the highest value under the baseline. 
to baseline levels at the fourth post-treatment month. The levels of LH and FSH exhibited a rebound elevation from three to five months after cessation of injections.

The treatment was associated with small but significant increase in the level of plasma glucose $(<10 \%)$, bilirubin $(<1 \%)$ and total protein $(<5 \%)$ while albumin level showed a decrease $(<5 \%)$ and returned to baseline by the end of the study. Plasma level of total cholesterol was increased by less than $10 \%$ at the fourth and fifth post-treatment month and remained lower than baseline values, at the end of the study. There were no significant changes in the level of highdensity lipoprotein cholesterol, serum glutamate-oxalate transaminase, serum glutamate-pyruvate transaminase or calcium.

Depot Medroxy Progesterone Acetate and Testosterone Enanthate or 19-Nortestosterone hexyloxyphenilpropionate

In the second study, ${ }^{9}$ male volunteers received either a combination of DMPA plus TE or a combination of DMPA plus 19-nortestosterone hexyloxyphenilpropionate (19-NT). In both cases DMPA (250 mg) was injected at week $0,6,12$, and 18 , and the TE (200 mg) or 19-NT (200 mg) was given weekly for the first seven weeks and then at three weekly intervals until week 24 . Twenty healthy male volunteers from each of five Indonesian centres (Palembang, Jakarta, Semarang, Surabaya and Denpasar) were randomized using sealed envelopes to one of the two treatment groups.
Suppression of sperm production was measured by semen analysis at three week intervals and clinical chemistry, hematology, and levels of gonadotrophin hormones were monitored at six week intervals. The recovery was assessed monthly until normal sperm concentration $\left(\geq 20 \times 10^{6} / \mathrm{ml}\right)$ was reached.

A total of 96 men were recruited to the study. Their anthropometric data, mean (SD), on entry were as follows: mean age was $34.7(5.8)$ years, height 162.6 (5.1) cm, weight $57.6(7.6) \mathrm{kg}$, Body Mass Index 21.8 (2.8) $\mathrm{kg} / \mathrm{m}^{2}$, testicular volume $22.4(5.3) \mathrm{ml}$.

The baseline semen characteristics varied from center to center. However, these factors were balanced across the two treatment groups, with the exception of sperm concentration, which was slightly higher in the TE group ( $P=0.05$, two-way ANOVA adjusted for between center differences). The median sperm concentrations (5th and 95th percentiles) were 46.3 (22.7, $123.2) \times 10^{6} / \mathrm{ml}$ in all men and $40.7(21.8,109.4)$ and $55.7(23.0,141.5) \times 10^{6} / \mathrm{ml}$ in the 19-NT and TE groups respectively. The mean (SD) levels among all men for hemoglobin, white blood cells, and platelet count were 145 (12) $\mathrm{g} / \mathrm{l}, 6.4(1.3) \times 10^{9} \mathrm{~h}$, and 241 (47) $\times 10^{9} / \mathrm{l}$, respectively, and did not differ between the two treatment groups.

Ninety of the 96 men completed the treatment phase. Of these, 87 (96.7\%; 95\% confidence interval, $90.6 \%$ to $99.3 \%$ ) achieved azoospermia (two or more consecutive azoospermic samples). The rate and degree of supression were similar in the two treatment groups (Figure 6) and in the different centres. Once azoosper-

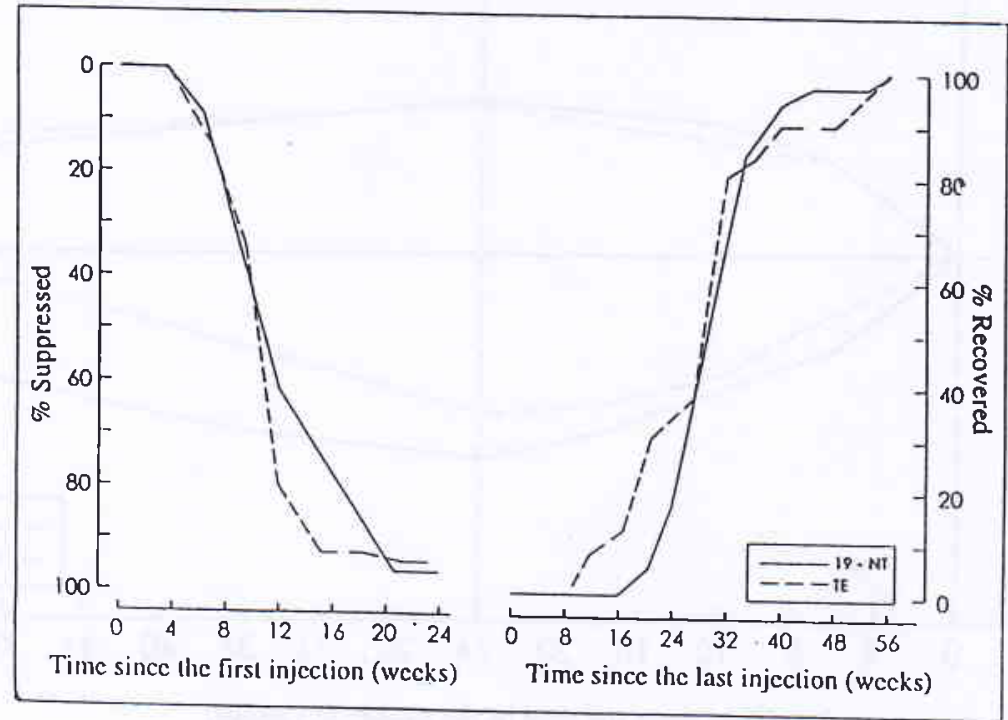

Figure 6. Cumulative rates of suppression to azoospermia (left panel) by the time since the first injection, and the recovery to the concentration of 20 million'ml (right panel) by the time since the last injection. 
mia in two samples was achieved, a subsequent increase in sperm production occurred in only one man during the treatment phase and his sperm concentration was only $0.4 \times 10^{6} / \mathrm{ml}$. The median time to recovery to normal sperm concentration $\left(\geq 20.0 \times 10^{6} / \mathrm{ml}\right)$ after the last injection was 6.5 months in those men who had achieved azoospermia (Figure 6). Two of the three men who failed to achieve consistent azoospermia had lowest sperm concentration of 0.1 and $0.8 \times 10^{6} / \mathrm{ml}$, respectively, and the third subject, only a single sample was azoospermic. These men were similar in anthropometric characteristics to the other men.

At the end of the treatment period the testicular volume, mean (SE) decreased by $12.8 \%(2.5 \%)$ and $9.9 \%(2.6 \%)$ while the body weight increased by $9.2 \%$ $(1.4 \%)$ and $8.8 \%(1.1 \%)$ in the $19-\mathrm{NT}$ and TE group, respectively. These parameters returned to pre-treatment levels six months after the last injection (Figure 7).

The plasma levels of FSH and LH were supressed during the treatment phase (Figure 8,9) and exhibited a rebound elevation between three and five months after the cessation of injections.

\section{COMPARISON BETWEEN VARIOUS DMPA- ANDROGEN REGIMENS}

These two studies demonstrate that the combination of progestogen with an androgen is highly effective in inducing azoospermia in normal Indonesian men.

In studies of DMPA plus TE carried out previously, only $14-70 \%$ of the subjects achieved azoospermia. ${ }^{4,10,11,12}$ In addition, a much higher combination dose of $300 \mathrm{mg}$ DMPA plus $250 \mathrm{mg}^{13}$ or $200 \mathrm{mg}$ DMPA plus $250 \mathrm{mg}$ testosterone cypionate ${ }^{14}$ was needed to achieve a cumulative rate of azoospermia in excess of $80 \%$.

It is particularly notable that the frequency of azoospermia or severe oligozoospermia induced by DMPA plus TE was higher in studies conducted in developing countries (e.g. Dominican Republic, ${ }^{13,15,16}$ and Brazil, ${ }^{17}$ than those conducted in North America and Europe. ${ }^{11,12,18,19,20}$ In the one other reported investigation using DMPA plus 19-NT, carried out in Germany, six out of 12 men reached azoospermia, and the sperm count in two more subjects were suppressed to near azoospermic levels. ${ }^{11}$

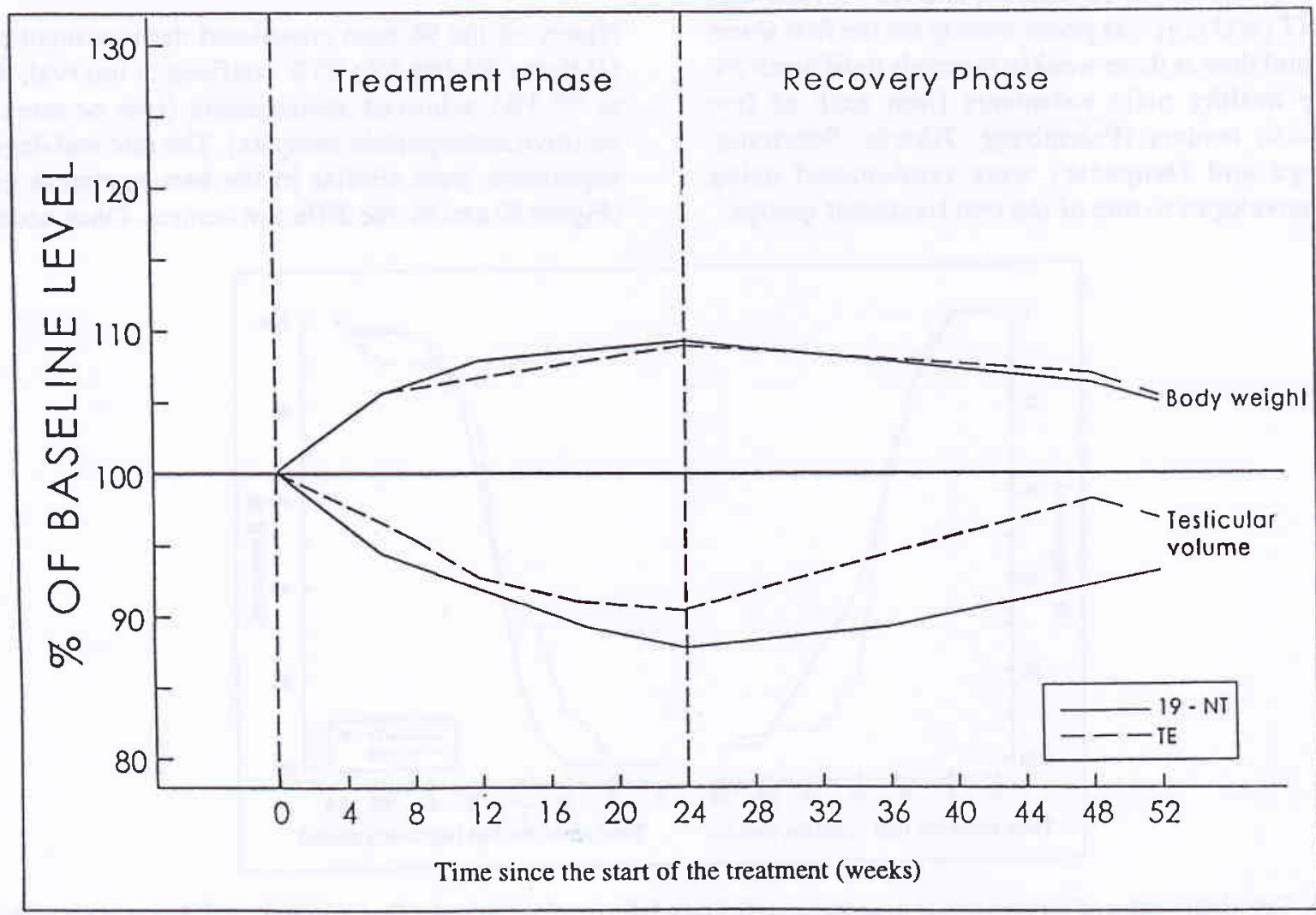

Figure 7. Changes in body weight and testicular volume (\% change from baseline) during and after treatment. 


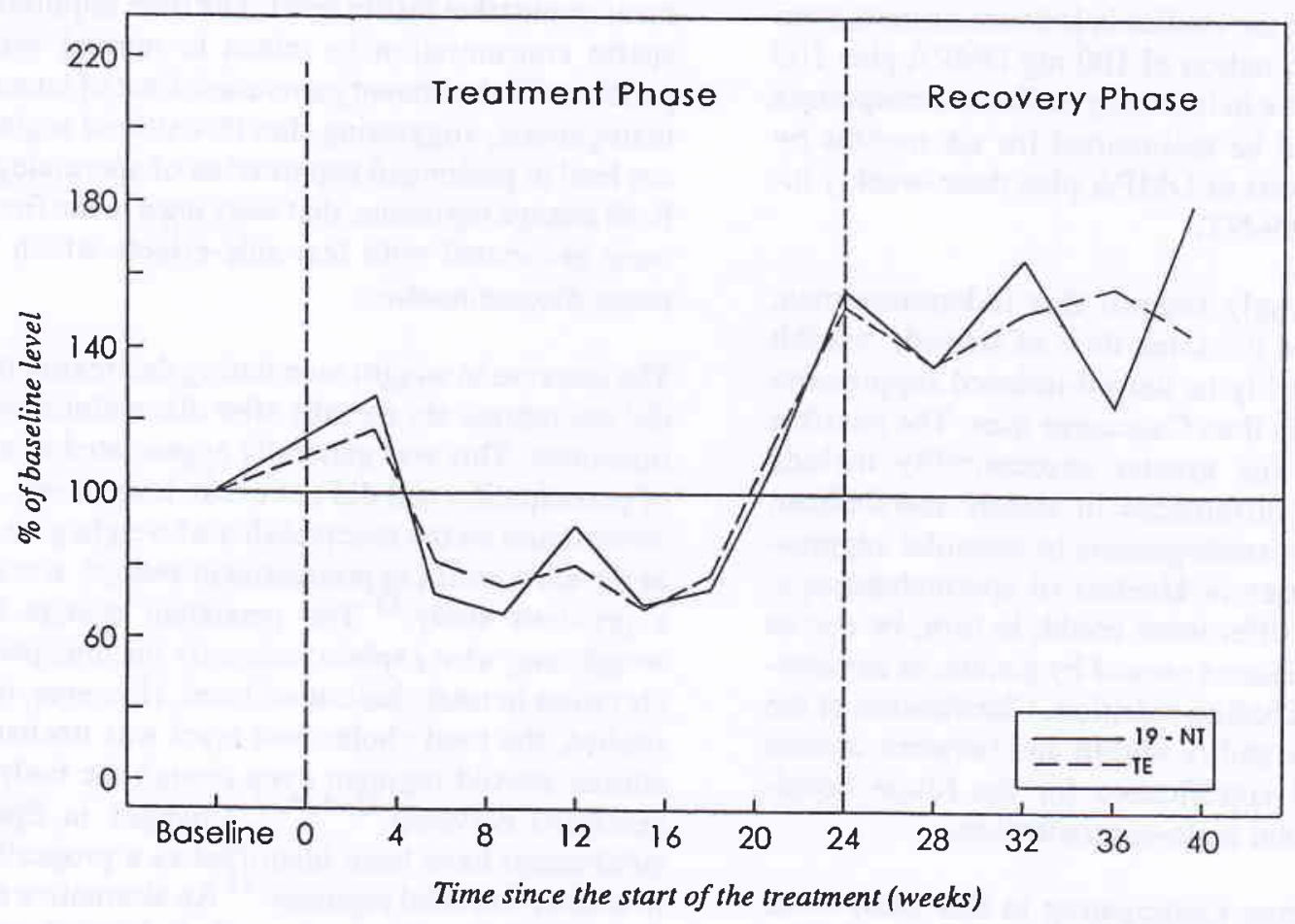

Figure 8. Changes in FSH concentration (\% change from baseline) during and after treatment

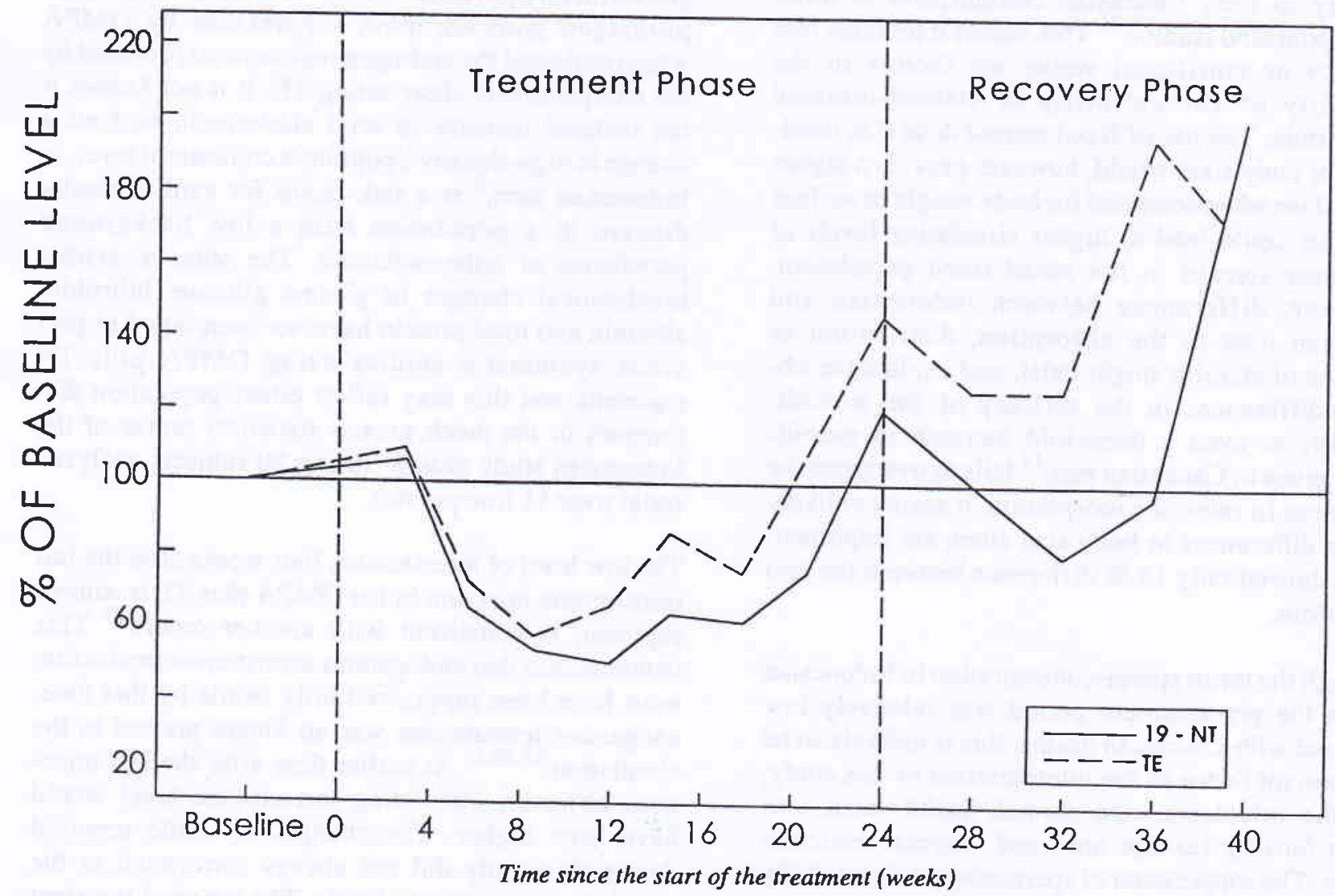

Figure 9. Changes in LH concentration (\% change from baseline) during and after treatment. 
It is striking that, in the studies in Indonesian men, even the low dose combination of $100 \mathrm{mg}$ DMPA plus 100 $\mathrm{mg}$ TE was effective in inducing uniform azoospermia and that this could be maintained for six months by six-weekly injections of DMPA plus three-weekly injections of TE or 19-NT.

These results strongly suggest that Indonesian men, when administered the same dose of steroids, exhibit a higher susceptibility to steroid-induced suppression of spermatogenesis than Caucasian men. The possible explanations for the greater susceptibility include population-based differences in steroid metabolism, insensitivity of spermatogenesis to steroidal suppression, or differences in kinetics of spermatogenesis. Such population differences could, in turn, be due to physiological variations caused by genetic or environmental factors, including nutrition. Clarification of the reason for the variability within and between centres will have crucial significance for the future development of hormonal male-contraception.

The Indonesian men participating in this study were smaller (shorter by $5.4 \%$, lighter by $11.3 \%$, smaller BSA by $8.6 \%$, lower BMI by $0.8 \%$ ) but of similar adiposity to their Caucasian counterparts in other WHO-sponsored studies. ${ }^{21}$ This makes it unlikely that adiposity or nutritional status are factors in the variability of susceptibility to steroid-induced azoospermia. The use of fixed steroid dose (i.e. unadjusted for body size) would, however provide a higher steroid-dose when corrected for body weight or surface area. This could lead to higher circulating levels of exogenous steroid in the small-sized population. Moreover, differences between Indonesian and Caucasian men in the absorption, distribution or clearence of steroids inight exist, and explain the observed differences in the efficacy of the steroids. However, as even a three-fold increase in steroiddosage given to Caucasian men ${ }^{13}$ fails to overcome the differences in rates of azoospermia, it seems unlikely that the differences in body size alone are important, as this showed only $15 \%$ difference between the two populations.

Although the mean sperm-concentration in Indonesian men in the pre-treatment period was relatively low compared with Caucasian norms, this is unlikely to be an important factor in the interpretation of this study, since the volunteers were normal, healthy men with proven fertility (except one) and normal testicular volume. The suppression of spermatogenesis was fully reversible after the cessation of injections, as indicated by the recovery of sperm concentrations to pre-treat- ment or putative fertile level. The time required for the sperm concentration to return to normal was compatible with the known generation-time of human spermatogenesis, suggesting that this steroid regimen did not lead to prolonged suppression of spermatogenesis. Both dosage regimens, that were used in the first study, were associated with few side-effects which did not cause discontinuation.

The increase in weight seen during the treatment phase, did not regress six months after discontinuation of the injections. This was generally appreciated as a benefit of participation and did not evoke complaints. Similar observation on the acceptability of weight gain, as well as the slow return to pretreatment weight, was noted in a previous study. ${ }^{13}$ The persistent change in body weight may also explain indirectly the unexpected late elevation in total cholesterol level. However, in earlier studies, the total cholesterol level was unchanged by similar steroid regimen even though the body weight remained elevated. ${ }^{13,15,16,22}$ Changes in lipoprotein subfraction have been identified as a progestin effect in similar steroidal regiment. ${ }^{22}$ An alternative explanation may be that the rise in total cholesterol, and fall in alkaline phosphatase, reflect the effects of hypogonadism on lipid metabolism ${ }^{23}$ and bone, ${ }^{24}$ due to the prolonged gonadotrophin suppression by DMPA which outlasted the androgen replacement provided by the comparatively short-acting TE. It is not known if the isolated increase in total cholesterol, without a change in high-density lipoprotein cholesterol level, in Indonesian men, ${ }^{8}$ is a risk factor for cardiovascular disease in a population with a low background prevalence of artherosclerosis. The other reversible biochemical changes in plasma glucose, bilirubin, albumin and total protein have not been noted in previous systematic studies using DMPA plus TE regimens and this may reflect either population differences or the much greater statistical power of the Indonesian study design (using 20 subjects analysed serial over 11 timepoints).

The low level of testosterone, four weeks after the last testosterone injection in the DMPA plus TE treatment regimen, is consistent with another report. ${ }^{20}$ This demonstrates that endogenous testosterone production must have been suppressed fully, while by that time, exogenous testosterone was no longer present in the circulation. ${ }^{25,26,27}$ At earlier time after the last injection, however, circulating testosterone level would have been higher. The changes in libido reported during this study did not always correspond to the circulating testosterone levels. The reported transient increase in libido immediately on starting treatment in 
most subjects, was probably a placebo reaction as normal circulating testosterone level would have been maintained. Conversely, the decline in libido reported by a minority of subjects following cessation of injections, may be attributed to the prolonged suppression of endogenous testosterone induced by DMPA, relative to the short duration of the effects of TE. $20,25,26,27$

Recent WHO-sponsored studies have demonstrated, for the first time, that hormone-induced azoospermia can be sustained reliably and is highly effective as male contraceptive. ${ }^{20}$ The present findings suggest that hormonal suppression of spermatogenesis may be an effective approach to male contraception in Indonesia and possibly other countries. A major limitation of the treatment regimen used in the multicentre study is the frequency of injections. Intramuscular injections of androgen weekly for seven weeks and then at three week intervals was chosen as the simplest prototype regimen because of its safety, reversibility, and effectiveness in inducing azoospermia. The pharmacokinetic properties of androgen preparations seem to be of critical importance in achieving azoospermia in men. The frequent complaints of loss of libido during treatment with 19-NT compared with TE could reflect differences either in the efficacy of 19-NT and $\mathrm{TE}$ or in dose equivalence of the two regimens used for androgen replacement. Both androgens act upon the same androgen receptor and exhibit similar androgenic and anabolic effects, as demonstrated by the similarity of their effect on androgen-sensitive variables in the second study (body weight, testis size, hemoglobin, LH and FSH). Nevertheless, differences in biological action are possible since 19-NT is nonaromatizable whereas the aromatization of $\mathrm{TE}$ to estradiol is involved in some effects of $\mathrm{T}$ on brain function. It remains controversial whether $19-\mathrm{NT}$ is able to support sexual function only partially ${ }^{28}$ or fully ${ }^{29}$ in orchidectomized monkeys. Alternatively, the efficacy of the 19-NT regimen for androgen replacement therapy, when administered at three-week intervals (as during maintenance phase in the second study), is less well established than that of $\mathrm{TE},{ }^{30}$ and could be less adequate.

Although very high rates of azoospermia was achieved in the multicentre study, ${ }^{9}$ a small minority of men (3 of $90,3.3 \%$ ) failed to reach consistently azoospermic level. The low concentrations of residual sperm, however, suggest that these men may also be rendered sufficiently infertile to equate reliable contraception. Indeed, the functional capacity of residual sperm during steroid-induced supression appears to be markedly decreased as judged by their impaired ability to fuse with zona-free hamster oocyte. ${ }^{31}$

\section{CONCLUSION}

The encouraging results obtained in these two studies offer a good prospect for developing a safe and effective hormonal contraceptive method suitable for use by Indonesian men. However, the frequency of injection and the high levels of hormones currently available that need to be injected would make the development of such a method difficult. To solve these problems, longer-acting androgens are being developed to be used either alone or in combination with a long-acting progestogens. It is planned that these preparations, which might be given at three-monthly intervals, will be assessed in Indonesian volunteers for safety, efficacy, reversibility and acceptability. These studies will include assessment of effects on behavior as well as the longitudinal impact on health status of the volunteers.

Appropriate study instruments will need to be developed to assess the acceptability of male hormonal contraceptive methods and to determine the preferred contraceptive methods for couples of reproductive age in Indonesia.

\section{REFERENCES}

1. WHO. Progress in Human Reproduction Research, Special Programme of Research, Development and Research Training in Human Reproduction. Geneva: WHO, 1994.

2. Homonnai TZ, Paz FG. Methods for evaluating contraceptive technique. In: Cunningham GR, Schill WB, Hafez ESE, editors. Regulation of male fertility. The Haque: Martinus Nijhoff 1980:41-50.

3. Patanelli DJ, editor. Hormonal control of male fertility. Washington: US Department of Health, Education and Welfare, 1978.

4. Schearer SB, Alvarez-Sanchez F, Anselmo J, Brenner PF, Coutinho E, Latham-Faundes A, et al. Hormonal contraception for men. Int J Androl 1978: suppl 2:680-712.

5. Nieschlag E, Behre HE, Weinbauer GH. Hormonal methods for the regulation of male fertility. In: Serio M, editor. Perspective in Andrology. Serono Symposia Publications volume 53. New York: Raven Press, 1989:517-29.

6. Swerdloff RS, Palacios A. Male contraception: Clinical assessment of chronic administration of testosterone enanthate. Int J Androl 1978: Suppl 2: 731-47.

7. Waites GMH. Male fertility regulation : The challenges for the year 2000. Br Med J 1993;49:210-21

8. Pangkahila W. Reversible azoospermia induced by an androgen-progestin combination regimen in Indonesian men. Int J Androl 1991;14:248-56.

9. World Health Organization. Comparison of testosterone enanthate plus DMPA and 19-nortestosterone hexoxyphenyl propionate plus DMPA for male contraception. Fertil Steril 1993;60(6):1062-8.

10. Knuth UA, Behre H, Belkein L, Bents H, Nieschlag E. 19-Nortestosterone for male fertility regulation. In: Zatuchni 
GI, Goldsmith A, Spieler JM, Sciarra JJ, editors. Male contraception, advances and future prospects. Philadelphia: Harper and Row, 1986:320-8.

11. Knuth UA, Yeung CH, Nieschlag E. Combination of 19 nortestosterone hexyloxyphenylpropionate (Anadur) and depot-medroxyprogesterone acetate (Clinovir) for male contraception. Fertil Steril 1989;51:1011-8.

12. Brenner PF, Mishell DR, Bemstein GS, Ortiz A. Study of medroxyprogesterone acetate and testosterone enanthate as a male contraceptive. Contraception 1977;15:679-91.

13. Alvarez-Sanchez F, Faundes A, Brache V, Leon P. Attainment and maintenance of azoospermia with combined monthly injection of depot medroxy progesterone acetate and testosterone enanthate. Contraception 1977;15:635-48.

14. Paulsen CA, Bremner WJ, Leonard JM. Male contraception clinical trials. In: Mishell DR Jr, editor. Advances in fertility research. New York: Raven Press, 1982;157-70.

15. Alvarez-Sanchez F, Brache V, Leon P, Faundes A. Inhibition of spermatogenesis with monthly injection of depot medroxy progesterone acetate and low dose testosterone enanthate. Int J Androl 1979;2:136-49.

16. Faundes A, Brache V, Leon P, Schmidt F, Alvarez-Sanchez F. Sperm suppresion with monthly injections of medroxyprogesterone acetate combined with testosterone enanthate at a high dose (500 mg). Int J Androl 1981;4:235-45.

17. Melo JF, Coutinho EM. Inhibition of spermatogenesis in men with monthly injection of medroxy-progesterone acetate and testosterone enanthate. Contraception 1977;15:627-34.

18. Frick J, Bartsch G, Weiske WH. The effect of monthly depot medroxyprogesterone acetate and testosterone on human spermatogenesis. I. Uniform dosage level. Contraception 1977; 15:649-68.

19. Frick J, Bartsch G, Weiske WH. The effect of monthly depot medroxyprogesterone acetate and testosterone on human spermatogenesis. I. High initial dose. Contraception 1977;15:669-77.

20. Hedman M, Gortleib C, Svanborg K, Bygdeman M, de la Torre B. Endocrine, seminal and peripheral effects of depot medroxyprogesterone acetate and testosterone enanthate in Men. Int J Androl 1988;11:265-76.
21. World Health Organization. Contraceptive Efficacy of testosterone induced azoospermia in normal men. Lancet 1990; 336:955-9.

22. Wallace EM, Wu FC. Effects of medroxy-progesterone acetate and testosterone enanthate on serum lipoprotein in Men. Contraception 1990;41:63-71.

23. Oppenheim DS, Greenspan SL, Zervas NT, Schoenfeld DA, Klibanski A. Elevated serum lipids in hypogonadal men with and without hyperprolactinemia. Annals of Internal Medicine. 1989;111:288-92.

24. Kasperk CH, Wergedal JE, Farley JR, Linkhart TA, Turner RT, Baylink DJ. Androgen directly stimulate proliferation of bone cells in vitro. Endocrinology 1989;124:1576-8.

25. Schulte-Beerbuhl M, Neischlag E. Comparison of testosterone, dihydrotestosterone, luteinizing hormone, and follicle-stimulating hormone in serum after injection of testosterone enanthate or testosterone cypionate. Fertil Steril 1980;33:201-3.

26. Sokol RZ, Palacios A, Campfield LA, Saul C, Swerdloff RS. Comparison of the kinetic of injectable testosterone in eugonadal and hypogonadal men. Fertil Steril 1982;37:42530.

27. Schumeyer T, Neischlag E. Comparative pharmacokinetics of testosterone enanthate and testosterone cyclohexanecarboxylate as assessed by serum salivary testosterone levels in normal men. Int J Androl 1984;7:181-7.

28. Michael RP, Bonsall RW, Zumpe D. The behavioural thresholds of testosterone in castrated male rhesus monkeys (Maccaca mulatta). Horm Behav 1984;18:161-76.

29. Weinbauer GF, Jaekwert B, Yoon YD, Behre HM, Yeung $\mathrm{CH}$, Nieschlag E. Pharmacokinetics and pharmacodynamics of testosterone enathate and dihydrotestosterone enanthate in non-human primates. Acta Endocrinol (Copenhagen) 1990;122:432-42.

30. Snyder PJ, Lawrence DA. Treatment of male hypogonadism with testosterone enanthate, J Clin Endocrinol Metab 1980;51:1335-9.

31. Wu FCW, Aitken RJ. Supression of sperm function by depot medroxyprogesterone acetate and testosterone enanthate in steroid male contraception. Fertil Steril 1989;51:691-8. 